\title{
EDITIONWATCH 1999
}

[99/1]

Braimah, J.A., H.H. Tomlinson, and Osafroadu Amankwatia. History and Traditions of the Gonja. Ed. P.L. Shinnie (African Occasional Papers, 6). Calgary: University of Calgary Press, 1997. Pp. viii+184.

\section{Editorial Principles}

The Braimah text, originally a typescript dating from before 1984 , is published "as it stood with minimal editing" by Shinnie. Tomlinson's text, a mineographed edition from 1954 that had had limited distribution is published "with minor editorial changes" and the approval of the author. The third document, apparently, was a text by Braimah (died 1987) that was given to Amankwatia, who "improved on it by further research" and made "some amendments," also before 1984. Other than the comment that "spellings have been left as the author gave them" there are no further indications of the extent of the editorial hand.

\section{Apparatus}

It is not entirely clear where the original authors stopped and the editor began. Clearly to be attributed to the latter is a brief introduction on the prehistory of the three texts, editorial notes on the Braimah text, and three maps. No attempt at updating (e.g., the lists of officeholders) has been made.

\section{Index/es}

None

Facsimiles of Holographs

Inapplicable 
[99/2]

Stairs, William G. African Exploits: the Diaries of William Stairs, 18871892. Ed. Roy MacLaren. Montreal: McGill-Queen's University Press, 1998. Pp. xvi +423.

\section{Editorial Principles}

Stairs was a member of the Emin Pasha Relief Expedition; his "final" diary of the occasion survives in five physical parts, was "neatly written in ink and almost entirely free of corrections or emendations," the result of "three years of writing and rewriting." (30) Thus the first text edition was that of Stairs himself, apparently with an eye to publication, which never eventuated since he died in 1892, still in Africa. The present edition is not a complete transcription of these materials, which ran to 145,000 words. As a result ellipses appear on virtually every page, but there is no evidence that modern editorial emendations have occurred-or have not. Some of the materials, so identified, are translated here from a French version published in 1893.

\section{Apparatus}

Long historical introduction, overviews preceding each of 23 chronological chapters; numerous textual notes of some length; 18 illustrations, largely of engravings from the period featuring Stairs' colleagues and adversaries, sketch maps, and travel scenes; two reports by Stairs, evidently not part of the diaries per se; skeletal bibliographical footnotes; bibliography.

\section{Index/es}

Subject index lacking sub-entries rendering access inefficient.

\section{Facsimiles of Holograph}

None 


\section{$[99 / 3]$}

Passarge, Siegfried. The Kalahari Ethnographies (1896-1898) of Siegfried Passarge: Nineteenth Century Khoisan-and Bantu-Speaking Peoples [Quellen zur Khoisan-Forschung 13]. Ed. Edwin N. Wilmsen, trans. Leander Gloversmith, Caroline Jeannerat, Edwin N. Wilmsen, and Klaus Keuthmann. Gaborone: Botswana Society; Köln: Rüdiger Köppe Verlag, 1997. Pp. 332.

\section{Editorial Principles}

Translations of six works published by Passarge between 1899 and 1907, as well as an exchange between Passarge and Gustav Fritsch regarding the former's Die Buschmänner der Kalahari, the longest text presented here. Most original punctuation is retained. Toponyms are modernized with Passarge's orthography provided at first mention. African words are shown as written and accompanied by their counterparts in modern orthography. These and other editorial interpolations are indicated in the usual ways. Photographs and line drawings are not reproduced, although their captions are gathered at the end of each text. The original pagination (all the texts originally appeared as articles) is also indicated to facilitate comparison.

\section{Apparatus}

A substantial introduction places Passarge's work in its intellectual and ethnographic contexts, and there are brief, but explicit, "editing notes." Each of the seven texts is extensively annotated, there being a total of 253 notes, many quite substantial, in the work. There is a frontispiece portrait of Passarge and one map from his writings. A long bibliography concludes the edition.

\section{Index/es}

There are no indexes

\section{Facsimiles of Holograph}

Not applicable 
[99/4]

Kaulinge, Vilho. "Healing the Land:" Kaulinge's History of Kwanyama. Ed. Patrica Hayes and Dan Haipinge. trans. Dan Haipinge. Köln: Rüdiger Köppe, 1997. pp. 97

\section{Editorial Principles}

None stated, although there is a discussion of the perceptual losses that accompany the transcription of an oral text into writing.

\section{Apparatus}

Editorial "preface," actually an introduction; four photographs of the informant; one historical map. Text (collected in 1989-90) consists of 167 numbered paragraphs dealing with Ovambo and Herero history during the colonial period. Each paragraph is presented first in Ovambo and then in English. There are no annotations.

\section{Index/es}

None

\section{Facsimiles of Holograph}

Not applicable 